\title{
structural, lexico-semantic and lingvocultural characteristics of the thematic group insectophnes in the english and russian languages
}

\author{
E. Razheva, O. Troshina
}

\author{
Bauman Moscow State Technical University (RUSSIAN FEDERATION)
}

\begin{abstract}
The article is devoted to the comparative analysis of the insects which are formed as an imitation of sounds made by motion and activity of insects in English and Russian. The content and structure of the thematic group which these names (called insectophones) constitute are defined. The research allowed classifying insectophones into seven groups according to the character of the sound insects produce. The analysis confirms that the most names of the insects are onomatopoetic by origin. The names of the twelve insects most frequently mentioned in both languages and sounds which were the basis of these names and the verbs which convey their motion are given in the table. Three types of imitation of sounds are described. As the research shows anthropocentric metaphor is a productive way of forming the thematic group in both languages (18 insectophones are formed in such a way in English and 12 in Russian). The thematic group includes a number of paroemias which are subdivided into five groups and a number of subgroups according to the meanings they convey. These groups and subgroups differ in number in English and Russian which they mean that a certain feature is more or less important for one or the other culture..
\end{abstract}

Keywords: paroemias; onomatopoeia; semantics; linguistic view of the world; anthropocentric metaphor.

\section{Introduction}

Today, the question of the sound-letter correlation, relationship between the form and the meaning is very relevant in modern linguistics. This article is devoted to phonosematics which deals with this issue. The issues of phonosemantics attract the attention of many researchers (Auracher, 2011 et al.), (Danilchuk, 2016), (Magnus, 2001), (Osgood, 1967), (Sapir, 1929), (Wagner). Besides, the article raises the questions not only a phonosemantic nature but also touches upon cultural linguistics aspects which issues are at the top of the linguistic research (Lado, 1957), (Shanohara \& Kawahara, 2012).

The objective of this article is a structural, lexico-semantic and lingvocultural analysis of the THEMATIC GROUP INSECTOPHONES using the example of two languages - English and Russian.

Names of insects are of interest for research because of the large number and tangible involvement of these invertebrate arthropod animals in the human world. The mention of any of more than a million known and today described insect species of the five largest orders (coleoptera, diptera, lepidoptera, hymenoptera, hemiptera) does not leave us indifferent. By 
endowing them with negative characteristics, we transfer these characteristics to other people. Despite the fact that bees can sting a careless person to death, the bee is perhaps the only insect in many cultures of the world which have been given only positive and noble traits for a long time.

Since ancient times, many nations of antiquity have myths and legends related to bees, which emphasize the noble role of a bee; the valuable properties of the honey and wax produced; reasonableness of the organization of the bee family. The goddess Artemis, the patroness of animals and hunting often depicted in the form of a bee. The image of a bee can be seen on the oldest coins of the world; Palestine, where beekeeping flourished, was once poetically called "the land where milk and honey flow." The bee in both lingvo-cultures is assessed as a hardworking and beneficial honey insect.

\section{Methodology}

The article is a brief overview of the deep and long research in the field of the theme group INSECTOPHONES. The procedure the authors followed for extracting insectophones and paroemias was based on using many different dictionaries (English-English, Russian-Russian, English-Russian, Russian-English, dictionaries of proverbs and saying, phraseological dictionaries).

With the help of the selected material the authors come to the idea of the concept of the insectophones and the theme group of insectophones. Then they try to classify insectophones according to the names of the insects and the sounds they produce.

During analysis of this theme group we conclude that metaphorization is a very productive way of formation in the given theme group.

This is of high importance not only for linguistics but also for teaching English. In recent years, some innovative approaches and techniques have been used in the development of course design, syllabuses, materials, teaching methods at Bauman Moscow State Technical University (BMSTU) (Gurova et al., 2018), (Tyurikov et al., 2018), (Nurieva et al., 2018), (Torubanova, 2016), (Shafikova et al., 2018), (Inozemtseva et al., 2019).

\section{ANALYS OF THE THEME GROUP INSECTOPHONES}

\subsection{The concept of the insectophones. Theme group INSECTOPHONES}

In the English linguistic culture, the names of the insect bee is: 1) "bee", a hardworking person; 2) meeting neighbors or friends (most often for work or mutual assistance) (Müller, 2005). Moreover, this name is also used as the female name Bee (Bi).

In the Russian lingvoculture, the name of пчела also revealed two meanings developed during metaphorical transference: 1) a hardworking person (the variant with the diminutive suffix of the bee is most often used пчелка); 2) a meek, industrious woman - a little bee (пчелочка) (Mokienko \& Nikitina, 2007). 
As you can see, the first meaning is the same in both lingvocultures.

It can be stated that in both linguistic cultures there is a transfer of the quality of a bee noticed by a person - diligence (or group in the English linguistic culture), possessing this quality.

To designate the name of an insect, but not any name, but only onomatopoeic, that is, phonetic onomatopoetic signals of the insect, lexico-phonetic names and lexical means of imitating the acoustic signal of an insect, we introduce the term insectophone into scientific use, which like a number of other linguistic terms used in another field of knowledge.

The term insectophone was used in livestock engineering to designate a device for "detecting the contamination of grain by pests by noise as they made." The term "insectpohone" is formed by analogy with the "zoophone".

The set of insectophones we consider as a thematic group, which elements serve as a means of reflecting the national-cultural British and Russian worldview. Their semantics is seen as a way of representing knowledge related to designated insects in the consciousness of lingvocultural community representatives.

Onomatopoeic names of insects and verbs denoting the sounds they emit have not yet received adequate attention in linguistics. Despite the fact that not every animal species acoustic (sound) communication holds such significant role in life as insects do.

Let's make a reservation that not all insects produce sounds and some of them are noiseless. We also should mention that insects do not have a vocal apparatus but they produce sounds when moving or harming a person (bloodsucking and biting, pitying).

\subsection{Classifications of insectophones}

Conducted research allowed us to develop a classification of insect names formed on the basis of the sound they emit during movement or the action they produce:

1) buzzing (most insectophones in both languages belong to this group: жук / beetle, комар / gnat, midge, mosquito, муха / fly, пчела / bee, стрекоза / dragonfly, шмель / humble-bee, bumble-bee, Dumbledore, шершень / hornet);

2) ringing (комар, пчела, кузнечик - in Russian, fly - in English);

3) humming (комар, пчела, шершень - in Russian, gnat, midge, mosquito; bee, dragonfly, humble-bee, bumble-bee, Dumbledore; hornet - in English);

4) tinkling (стрекоза/ dragonfly);

4) crackling (стрекоза/ dragonfly, сверчок / cricket);

5) suction sound (комар/ gnat, midge mosquito; пчела/ bee; паук / spider);

6) bite sound (пчела, шершень; fly, bee, humble-bee, bumble-bee, Dumbledore; hornet). 
The names of some insects are simultaneously motivated by several sounds they produce. So, the name комар /gnat simultaneously conveys the sound of buzzing, ringing, buzzing and suction, пчела/ bee - the sound of buzzing, suction and bite.

Analysis of the names of insects in both languages confirms that most of them are onomatopoetic in origin.

The analysis revealed the names of the twelve most common insect species in both languages, the verb sounds and the sounds that formed the basis of the names themselves and the verbs that convey the sounds produced by each insect (see: Table 1).

Table 1: Insect names and corresponding verbs-sound meanings in Russian and English

\begin{tabular}{|c|c|c|}
\hline Name of insect & $\begin{array}{c}\text { English verbs of sound } \\
\text { designations }\end{array}$ & $\begin{array}{c}\text { Russian verbs of sound } \\
\text { designations }\end{array}$ \\
\hline Жук / beetle & $\begin{array}{c}\text { Zzz-zz-zz } \\
\text { bzz } \\
\text { buzz }\end{array}$ & $\begin{array}{c}\text { Жж } \\
\text { жу-жу-жу } \\
\text { жужжать }\end{array}$ \\
\hline $\begin{array}{l}\text { Kомар / gnat, } \\
\text { midge mosquito }\end{array}$ & $\begin{array}{c}\text { Bzz } \\
\text { buzz, tickle, bite, suck } \\
\text { sip, hum }\end{array}$ & $\begin{array}{c}\text { зум-зум-зум } \\
\text { пищать, жужжать, гудеть, } \\
\text { звенеть, ныть, зудеть, } \\
\text { журчать }\end{array}$ \\
\hline Myxa / fly & $\begin{array}{c}\text { Zzz-zz-zz } \\
\text { bzz } \\
\text { buzz, zoom, sting, tickle }\end{array}$ & $\begin{array}{c}\text { Жж } \\
\text { Вжу-вжу, вжи-вжи } \\
\text { Жужжать } \\
\end{array}$ \\
\hline Пчела / bee & $\begin{array}{c}\text { Zzz-zz-zz } \\
\text { bzz } \\
\text { buzz, sting, drone, hum } \\
\text { sip }\end{array}$ & $\begin{array}{c}\text { зум-зум-зум } \\
\text { жу-жу-жу } \\
\text { жжу, жи-жи } \\
\text { жужжать, жалить, гудеть, } \\
\text { зудеть, звенеть, роиться }\end{array}$ \\
\hline Сверчок / cricket & $\begin{array}{l}\text { Zzz-zZ-zZ } \\
\text { chirp-chirp } \\
\text { rustle, chirp }\end{array}$ & $\begin{array}{c}\text { тррр-тррр } \\
\text { цик, цвикать, чирикать, } \\
\text { трещать, стрекотать, } \\
\text { свистеть, трюкать }\end{array}$ \\
\hline Стрекоза / dragonfly & Hum, bomb & $\begin{array}{c}\text { стр-стр } \\
\text { егозить, трещать, } \\
\text { жужжать, греметь }\end{array}$ \\
\hline $\begin{array}{c}\text { Шмель / humble-bee, } \\
\text { bumble-bee, Dumbledore }\end{array}$ & $\begin{array}{l}\text { zzz-zz-zz, bzz, buzz, sting, } \\
\text { hum }\end{array}$ & $\begin{array}{c}\text { ж-ж-ж } \\
\text { жужжать, гудеть }\end{array}$ \\
\hline Кузнечик / grasshopper & $\begin{array}{l}\text { Chirp-chirp, chirp, rattle, } \\
\text { drum, husk }\end{array}$ & стрекотать, звенеть \\
\hline Шершень / hornet & Sting, hum, buzz & $\begin{array}{c}\text { шипеть, гудеть, жалить, } \\
\text { жужжать }\end{array}$ \\
\hline Бабочка / butterfly & Fly & Порхать \\
\hline $\begin{array}{c}\text { Паук / spider } \\
\text { (паук is not onomatopoetic) }\end{array}$ & $\begin{array}{c}\text { bite(small spider) } \\
\text { chomp(big spider - the sound } \\
\text { of biting) }\end{array}$ & Сосать \\
\hline $\begin{array}{c}\text { Моль / moth } \\
\text { (моль is not onomatopoetic) }\end{array}$ & $\begin{array}{l}\text { Tick (the sound, buzzing of a } \\
\text { small fly hitting the glass) }\end{array}$ & --------- \\
\hline
\end{tabular}

The study allowed us to select and systematize the types of comparison by the sound of insects with other objects of reality: 
1) comparison with other representatives of the fauna (animals, birds):

a) reptiles - hissing (hornet),

b) birds - chirp - tweet (cricket);

2) comparison with inanimate objects: bomb (dragonfly), drum (grasshopper), buzz (bumblebee, bee, hornet), ring (gnat);

3) comparison with a person: husk (grasshopper), sing (cricket, bee, mosquito, dragonfly and grasshopper), whistle (cricket).

\subsection{Methaphorization as a method of word formation in the thematic group of insectophones}

The composition of the thematic group "insectophones" in both languages is actively replenished through the process of metaphorization. The anthropocentric metaphor is used, which is formed according to the model: man <insect; and insect <man; subject <insect; insect $<$ item. This anthropocentric metaphor is based on the transfer of character traits, the physical characteristics of a person, and the characteristics of objects on an insect.

Metaphorization is a more productive way to form new words in English. The structure of the English thematic group includes eighteen insectophones formed with the help of a metaphor, the structure of the thematic group in the Russian language is twelve.

\subsection{Insectophones paroemias}

A significant role in the thematic group insectophones occupy the paroemia. In the Russian language, two hundred and twenty-seven paroemias were found, formed on the basis of a insectophone, in English - one hundred and ninety-six paroemias. Among the paroemias one can distinguish several groups united by the value transmitted by them.

This is a group of paroemias united by the common meaning "physical characteristics of a person" and consisting of subgroups:

1.1. Small / low (Eng. - 3 paroemias: knee-high to a grasshopper, be knee-high to a grasshopper, (to be) knee-high to a mosquito, Rus. - 0 paroemias);

1.2. Unattractive / repulsive (Eng. - 3 paroemias: bulldog chewing a wasp, beetle-browed, beetle-crusher, Rus. - 2 paroemias: стрекозьи ножки, как муху проглотил);

1.3. Attractiveness (Eng. - 1 paroemia: wasp waist, Rus. - 1 paroemia: талия как у осы (осиная талия));

1.4. Age (Eng. - 4 paroemias: when bees are old, they yield no honey; be knee-high to a grasshopper; (to be) knee-high to a mosquito; buzz-buggy, Rus. - 1 paroemias: летела мухагорюха да дунула в ухо стару старику за нову новину); 
1.5. Health (Eng. - 3 paroemias: (as) fit as a flea; flies haunt (go to) lean horses; the lean dog is all fleas, Rus. - 5 paroemias: его муха крылом перешибет; чует муха, где струп есть; к мокрому телку и муха льнет; благая муха укусила; черные мухи в глазах летают);

1.6. Physical disabilities (Eng. - 4 paroemias: blind as a beetle; deaf as a beetle; bee stings; mosquito bites, Rus. - 0 paroemias);

1.7 Strength / weakness (Eng. - 1 paroemias: sting and ling, Rus. - 13 paroemias: мала блошка, да колодой ворочает; не велик сверчок, да громко поет; вырос наш жук с медведя; вцепился / впился как клещ; и комары лошадей заедают (в южных камышах); ино от комара да в две руки не отмашешься; невеличка блошка, а спать не дает; и муха укусит, так вспухнет; комар тонко, да звонко; сверчок тму таракан (Тмутаракань) победил; ударил, как муха крылом задела; как в комаре сила; это комар на себе унесет; как петровский комар);

1.8 Satiety / hunger (Eng. - 0 paroemias, Rus. - 7 paroemias: в поле и жук мясо; живем не мотаем, а пустых щей не хлебаем: хоть сверчок в горшок, а все с наваром бывает; таракан не муха, не взмутит брюха; разъелся как вошь в корсете; и муха набивает брюхо; и муха не без брюха; мед сладко, а муха падко; прожорлив как саранча);

1.9. Intoxication (Eng. - 5 paroemias: drink with the flies (have one with the flies); full as a tick; tight as a tick; see pink spiders; pink spiders, Rus. - 3 paroemias: под мухой; с мухой (с мухой в голове); муху раздавить; муху зашибить);

1.10 Death (Eng. - 5 paroemias: butterfly kiss; a dead bee makes no honey; dying flies spoil the sweetness of the ointment; 'Almost' never killed a fly; to swat a fly, Rus. - 3 paroemias: мрут (дохнут) как мухи; промеж жизни и смерти и блошка не проскочит; попы поют над мертвыми, комары над живыми);

1.11 Mobility (Eng. - 3 paroemias: as quick as a bee; as brisk as a bee; (as) fit as a flea, Rus. - 5 paroemias: увертлив как блоха; за блохой, да за зайцем не поспеешь; прытка (бойка) блоха, да и та в пальцах вязнет; порхать как бабочка, порхать как мотылек; мотылек вителек: прытко летает).

As the analysis shows, the occupancy of some groups coincides (with the value of attractiveness), slightly differs (with the value unattractive, health, intoxication, death, mobility) and significantly differ (strength / weakness, satiety / hunger).

The second group of paroemias conveys the meaning of "psychological character traits of a person" and includes several subgroups:

2.1. Courage / cowardice (Eng. - 1 paremmia: get (have) butterflies in one's stomach, Rus. - 1 paroemia: муха не боится обуха)

2.2. Kindness (Eng. - 1 paroemia: one wouldn't hurt a fly, Rus. - 5 paroemias: мухи не обидит; ни мухам ворог; комар - он и во сне комара не убьет; и комар лошадь свалит, коли волк подсобит; в чужой сорочке блох искать)

2.3. Annoyance / obsession (Eng. - 6 paroemias: like flies; like a fly on shit; gad-fly; to stick like a leech, a limpet, a flea to a fleece; put a bug in smb's ear (in the ear of smb.); to swat a fly, 
Rus. - 18 paroemias: жужжать над ухом как муха; облепить со всех сторон словно мухи; народить как мух; неотвязчив как муха; как муха к меду льнет; наянлив, что муха, и стыда во лбу нет; пристает, как муха, на сон грядущий; жужжать, липнуть, как мухи; слетаться как мухи на мед; докучлив, как Ильинская муха; хорониться, как собака от мух; зудеть / жужжать над ухом как комар; впился / вцепился как клещ; как оса лезет в глаза; не сверчи в ушах, надоедаешь; мошка, да третья вошка, а от них упокою нет; солдатская вошь; брать как вошь солдата)

2.4. Levity / carelessness (Eng. - 4 paroemias: (as) light as a butterfly; a social butterfly; like a moth to the flume / candle (like moths around a flame(candle)); to have a grasshopper mind, Rus. - 1 paroemia: порхать как бабочка)

2.5. Arrogance / pride (Eng. - 4 paroemias: a fly on the (coach) wheel; fly sat upon the axletree of the chariot-wheel and said, what dust I raise; eagles don't catch flies; Presidential bee, Rus. - 4 paroemias: орел мух не ловит; зазнался, что вошь в корсете; идет, как вошь на чело ползет; блошка по саду гуляла, вошка кланялась, да блошка чванилась)

2.6. Greed (Eng. - 2 paroemias: flay a flea for the hide and tallow; skin a flea for its hide; Rus. - 5 paroemias: прожорлив как саранча; не напахать на комара опары: и пьет и хлебает; налетать (со всех сторон) как саранча; сколько ни дуйся, клещ, а видно, отвалишься; из блохи голенище кроит).

2.7. Cheerfulness / activity (Eng. - 8 paroemias: (as) chirpy (lively) as a cricket; as merry as a cricket; enough to make a fly laugh; a busy bee; (as) busy as a cockroach on a hot stove; there are no flies about (on) smb.; like a blue-assed fly; buzz about like a blue-assed fly, Rus. - 2 paroemias: порхать как бабочка; вертится, как вошь на гашнике (на поясе))

2.8. Stupidity / intelligence (Eng. - 9 paroemias: crush a fly with a steam-roller; strain at a gnat and swallow a camel; to break a butterfly on the wheel; take not a musket to kill a butterfly; flea-brained; have a grasshopper mind; beetle - head; bee-fool; there are no flies about (on) smb., Rus. - 11 paroemias: за мухой - не с обухом, за комаром - не с кнутом (топором); на комара с кистенем, на таракана с рогатиной; на комара с рогатиной; орлом комара не травят; на дурака и мухи садятся; на дурака и муха падка; думал много, да и вошь поймал; и у жука рог, да петушьего бодня не стоит; топором только блох ловят; комар парню ногу отдавил; не летит пчела от меду, а летит от дыму)

2.9. Talkativeness / silence (Eng. - 6 paroemias: he changes a fly into an elephant; hum and haw; shoot the breeze; a shut mouth catches no flies; be a fly on the wall; as dumb as a beetle, Rus. - 17 paroemias: делать из мухи слона; из комара делают слона; делать из комара вола; из блохи сделали слона; блоха с лошадь, а вошь с корову; зудеть / жужжать над ухом как комар; жужжать над ухом как муха; брюзжит, как муха в осень; жужжать как жук; гудеть как пчелы в улье; скрипеть / верещать как сверчок; не сверчи в ушах, надоедаешь; гудеть / жужжать как шершень; подай косаря - казнить, рубить комара; нет не жук, а жучиха; слышно, как муха пролетит; ша, муха, я - дихлофос (комар)!))

2.10. Individuality (Eng. - 14 paroemias: have bees in the head; have a bug up one's ass; get (have) butterflies in one's stomach; bug-eyed; go bug eyed; dull as a beetle; ho-hum; have blood like gnat's piss; moth-eaten; as gaudy as a butterfly; honey is sweet, but the bee stings; bees 
that have honey in their months have stings in their tail; the human tongue is more poisonous than a bee's sting; even a flea can bite, Rus. - 9 paroemias: загаженный мухами; как вошь в корсете; нет пчелки без жальца; пчела жалит жалом, а человек словом; жало остро, а язык острей того; как жук в навозе копается; зарылся, как жук в навоз; только жук, в навозе живучи, да чисто обихаживается; бывает, что и вошь кашляет).

The identified subgroups differ in fullness and indicate that some psychological features are given equal attention in both linguistic cultures (for example, courage / cowardice), attention to other features varies slightly (for example, stupidity / intelligence) and a number of features are given much more attention in one linguistic culture than in the other (in Russian linguistic culture it is kindness, obsession, greed, talkativeness); in English lingvoculture (carelessness, cheerfulness).

The third group consisted of paroemias that convey the meaning of "the emotional and psychological state of a person" and include subgroups that convey the following meanings:

3.1. Love (Eng. - 7 paroemias: be bitten by the bug; catch the bug; travel bug; catch fleas for smb.; If you want to live and thrive, let the spider run alive; take the sting out of smth.; Bedbug, Rus. - 2 paroemias: люди рады лету, а пчела цвету; пастух ради лета, пчела ради цвета)

3.2. Hate (Eng. - 6 paroemias: a flea in one's ear; with a flea in one's ear; send away (off) with a flea in one's ear; with a lash (whip) of scorpion; sting to the quick; sting like a wasp, Rus. - 7 paroemias: жалить как оса; рассердившись на блох, да и всю шубу в печь; я тебе посажу блошку за ушко; посадили блоху за ухо, да и чесаться не велят; люблю, как клопа в углу: где увижу, тут и задавлю; пчела жалит жалом, а человек словом)

3.3. Desire / Fad / Temptation (Eng. - 5 paroemias: a bee in one's bonnet; buzz bug; Presidential bee (in one's bonnet); honey is sweet, but the bee stings; you must lose a fly to catch a trout, Rus. - 7 paroemias: летит комар и муха); прытка (бойка) блоха, да и та в пальцах вязнет; на красный цветок и пчела летит; на хороший цветок летит и мотылек; как сонная муха; чует муха, где струп есть)

3.4. Rage (Eng. - 9 paroemias: sting like a wasp, angry as a wasp; a flea in one's ear; go away with a flea in one's ear; send smb. away (off) with a flea in his ear; women are like wasps in their anger; mad as a hornet; bring a hornets' nest about one's; stir up a hornet's nest, Rus. 11 paroemias: жалить как оса; осье, осиное гнездо; посадили блошку за ухо, да и чесаться не велят; осиное гнездо не берегут, а жгут; осиного гнезда не тронь; шмелиное гнездо; прихлопнуть точно муху, рассердившись на блох, да и всю шубу в печь; мошка-крошка, а человеческую кровь пьет; блошка куснет, и то зудит: а от мошки - волдыри; отмахиваться как от мухи)

3.5. Sadness / Consolation (Eng. - 3 paroemias: butterfly upon the wheel; the mother of mischief is no bigger than a midge's wing; big fleas have little fleas upon their backs to bite them, Rus. - 9 paroemias: попала собаке блоха на зуб; не укусывала его своя вошь; барчонок горя не вкусит, пока своя вошь не укусит; не укусывала тебя твоя блоха (вошь); важность, что вошь в пироге: хорошая стряпуха и два запечет; и у соборных попов не без клопов; кормить вшей (клопов, блох); попасться, как вошь во щепоть; изняла блошка, да вошка, да третья мошка). 
This group contains subgroups that slightly differ in terms of occupancy and one subgroup which occupancy significantly differs in the compared languages (with the meaning love).

The fourth group of paroemias is united by the meaning of "the relationship between man and society" and includes subgroups:

4.1. Social hierarchy (Eng. - 8 paroemias: be the bee's knees; social butterfly; a humble bee in cowturd thinks himself a king; it's plain as a bumble bee on a fried egg; if you want to live and thrive, let the spider run alive; bar-fly; the Indian elephant cares no for a gnat; eagles don't catch flies, Rus. - 16 paroemias: блоха блоху не ест; комар комару ногу не отдавит; слоны трутся меж себя комаров давят; орел мух не ловит; каждый (всяк) сверчок знай свой шесток; все сверчки по своим запечьям сидят; держись вошь своего тулупа; мужику рожь, а бурлаку вошь; где попы, там и клопы (а у мужика тараканы); блошка по саду гуляла, вошка кланялась, да блошка чванилась; служивый, что муха, где щель, там и постель, где забор, там и двор; всякая козявка в букашки лезет; жуку нора за обычай; жуку нора, а волку зима за обычай; ночная бабочка; дневная бабочка)

4.2. Welfare (Eng. - 16 paroemias: when bees are old, they yield no honey; dead bee makes no honey; flea-bitten; flea bag; flea house; chinch-pad; buzz-buggy, Rus. - 13 paroemias: где когтем поскребешь, там и вошь (грош); в одном кармане вошь на аркане, в другом блоха на цепи; вшей за гашником (гашник, гасник; вшивый гашник; из блохи не сошьешь дохи; долгов, что блох - не оберешься; нужда - мизгирь (паук), а заемщик, что муха (займы); вошь, как заемный грош, спать не дает; клещ не вещь, где упал, там и пропал; кабы вошку в сошку (соху), а блошку в борону)

4.3. Family (Eng. - 2 paroemias: I rather would a husband wed with a beetle brow than a beetle head; the birds and the bees), Rus. - 9 paroemias: под добрую сваху комар носа не подточит; знай сверчок свой шесток; комар комара нарожает, а человек человека; жуку нора, а волку зима за обычай; лебедь по поднебесью, мотылек над землей, всякому свой путь; без матки пчелки - пропащие детки; народить, как клопов; на вдове жениться, что стары штаны надевать: не вошь, так гнида)

4.4. Interpersonal relationships (Eng. - 4 paroemias: He that lies down with dogs must rise up with fleas; the best cloth may have a moth in it; dying flies spoil the sweetness of the ointment; a fly in the ointment, Rus. - 14 paroemias: с собаками ляжешь - с блохами встанешь; блох много; заблошиться; у всякого своя блошка, своя вошка, своя забота; блох из него выколачивать; ловить (выискивать) блох; в чужой сорочке блох искать; из собаки блох не выколотишь; собака и в собольей шубе блох найдет; блоха блоху не ест; комар комару ногу не отдавит; Макар да кошка - комар да мошка; не вши едят, а гниды; не вошь ест, а гнида точит )

4.5. Loneliness (Eng. - 0 paroemias, Rus. - 2 paroemias: одна пчела немного меду натаскает; недавно со двора, а вошь изняла)

4.6.1. Dilligence (Eng. - 7 paroemias: as brisk as a bee; busy bee; bee that gets honey doesn't hang around the hive; (as) busy as a cockroach on a hot stove; while honey lies in every flower, no doubt, it takes a bee to get the honey out; where there is honey to be found, there will be bees; to kill two flies with one flap, Rus. - 9 paroemias: трудолюбив как пчела; трудиться 
как пчел(к)а; смиренна, как агнец; делова как пчела; красна, что райская птица; верна, что горлица; делова, что пчела; не на себя пчела работает; пчела трудится - для бога свеча пригодится; на праздник и у комара сусло; принялся за дело, как вошь за тело; не погнетши пчел, меду не есть)

4.6.2. Idleness (Eng. - 3 paroemias: a fly sat on the horse's back and said: "We ploughed together"; The dog that is idle barks at his fleas, but he that is hunting them not; cubicle drones, Rus. - 8 paroemias: трутням праздник и по будням; трутни трудами других живут; давить блох; считать мух; ловит мух ртом; лохматить бабочку; словом комара не убьешь; кабы вошку в сошку (соху), а блошку в борону)

4.6.3. Craftsmanship (Eng. - 3 paroemias: nothing must be done hastily but killing of fleas; spelling bee; green hornet, Rus. - 10 paroemias: спешка нужна только при ловле блох; комар носа не подточит; блоху подковать; блоху на цепь приковали; мала блошка, да колодой ворочает; не плоха и блоха; невеличка блошка, а спать не дает; не велик сверчок, да громко поет; мошка - крошка, а человеческую кровь пьет; плохие пчелы - плохой и мед)

4.6.4. Professions (Eng. - 6 paroemias: beetle-crusher; shoo-fly; cubicle drones; mindless cubicle drones; Queen's bee; bee's knees, Rus. - 2 paroemias: служивый, что муха: где щель, там и постель, где забор, там и двор; подле пчелки в медок, подле жука - в навоз)

4.7.1. Deeds (Eng. - 4 paroemias: strain at a gnat and swallow a camel; crush a fly with a steam-roller; to break a butterfly on the wheel; take not a musket to kill a butterfly, Rus. - 3 paroemias: за мухой - не с обухом, за комаром - не с кнутом (топором); какая муха тебя укусила; едят тебя (его, ее, вас, их) мухи)

4.7.2. Deviant behavior (Eng. -1 paroemias: he that steal honey should beware of the sting, Rus. - 3 paroemias: ужалила пчела - два мерина со двора; мухарь проскочит, а мошка увязнет; трутни горазды на плутни)

Subgroup occupancy varies and they are especially distinguished sharply by this parameter with the meaning of social hierarchy, family, interpersonal relations, idleness, skill.

The fifth group includes paroemias which convey the meaning of "the attitude of man towards life”. This group includes the following subgroups:

5.1. Life experience (Eng. - 17 paroemias: where bees are, there is honey; bees that have honey in their months have stings in their tail; honey is sweet, but the bees sting; bees are old, they yield no honey; no bees, no honey; a dead bee makes no honey; he that steal honey should beware of the sting; pleasure has a sting in its tail; a sting in its tail; the human tongue is more poisonous than a bee's sting; nothing stings like the truth; the sting of a reproach is in its truth, a truth has thorns; nothing must be done hastily but killing of fleas; fly follows the honey; honey catches more flies than vinegar; you must lose a fly to catch a trout; laws catch flies, but let hornets go free, Rus. - 32 paroemias: пчела жалит жалом, а человек словом; жало остро, а язык острей того; блоха проскочила, стол повалила; спешка нужна только при ловле блох; скоро блох ловят; на ветру хорошо блох ловить, смирны; блюди рогожу, а шубу вши съели; слетаться как мухи на мед; где мед, там и мухи; будь лишь мед, мух много нальет; была бы изба нова, а сверчки будут; сверчки наперед хозяина перебрались в 
новый дом; была бы голова, а вши будут; кусают комар до поры; муха не прокусит брюха; осенняя муха больнее кусает; муха кусает до Ильина дня, питается; после Ильина дня запасается; плохие пчелы - плохой мед; не летит пчела от меду, а летит от дыму; ужалила пчела - два мерина со двора; и у осы мед есть; осиное гнездо не берегут, а жгут; осиное гнездо не тронь; из собаки блох не выколотишь; собака и в собольей шубе блох найдет; ищи, как собака блох ищет; орлом комара не травят; в поле и жук мясо; держишь вошь своего тулупа; всякое трафляется, и жук в навозе капается; правда, что у мизгиря в тенетах: шмель пробьется, а муха увязнет; закон, что паутина: шмель проскочит, а муха увязнет)

5.2. Good luck / bad luck (Eng. - 2 paroemias: (as) snug as a bug in a rug; as cosy as a bug in a rug, Rus. - 4 paroemias: кому скромным куском подавиться - хоть век постись, комара проглотишь - подавишься; где муха ни летала, а к пауку попала; ешь вошь, а будет и грош; купить, что вошь убить, а продать, что блоху поймать)

5.3. Attitude towards God and ministers of religion (Eng. - 0 paroemias, Rus. - 6 paroemias: пчела трудится - для бога свеча пригодится; муравей не по себе ношу тащит; да никто спасибо ему не говорит; а пчела по искорке носит, да богу и людям угождает; пчела божья угодница; пчела жалит только грешника; где попы, там и клопы; попы поют над мертвыми, комары над живыми).

The three subgroups identified are significantly different in terms of occupancy.

\section{Conclusion}

The conducted analysis allows us to draw some conclusions about the greater or lesser significance of a particular characteristic of a person for one of the compared lingvocultures.

1) The article attempts to make a comparative analysis of the onomatopoetic names of insects in the English and Russian languages.

2) The study allows to distribute classified insectophones into seven groups according to the sound they produce.

3) The analysis confirms that most insect names are imitative in origin.

4) Three types of sound imitation are described.

5) The anthropocentric metaphor is a productive method of education in the studied subject group in both languages (18 insect phones are formed in this way in English and 12 in Russian)

6) The thematic group includes a certain number of paroemias, which are divided into 5 groups.

Thus, the subject group is an interesting subject for study. 


\section{References}

[1] Auracher, J., Albers, S., Zhai, Y. et al. (2011). P is for happiness, N is for sadness: Universals in sound iconicity to detect emotions in poetry. In Discourse processes, 48 (1), p. $1-25$.

[2] Danilchuk, M.V. (2016). The potential of phonosemantic analysis in the naming process in marketing. In Newsletter of the Herzen State Pedagogical University of Russia 181, p. 2935 .

[3] Gurova G.G.. Reznik S.V., Shafikova I.R. (2018). New materials and developing English language competence in university students and teachers. IOP Conf. Series: Journal of Physics: Conf. Series, no. 1134 (2018) 012019 IOP Publishing doi:10.1088/17426596/1134/1/012019Karpov A.O. (2015). "Formation of the Modern Concept of Research Education: from New Age to a Knowledge Society", Worldwide Trends in the Development of Education and Academic Research, Procedia Social and Behavioral Studies, vol. 214, pp. 439-447.

[4] Inozemtseva, K.M., Troufanova, N.O., Krupchenko, A.K. (2019). Professional Development Model for ESP Teachers Working at Engineering Universities. Vysshee obrazovaniie v Rossii - Higher Education in Russia, vol. 28, no. 1, pp. 147-158. (In Russ., abstract in Eng.).

[5] Lado, R. (1957). Linguistics Across Cultures. Ann Arbor: University of Michigan Press.

[6] Magnus, M. (2001). What's in a word? Studies in phonosemantics PhD dissertation. Trondheim: University of Trondheim. [Online]. Available: http://www.trismegistos.com/Dissertation/dissertation.pdf

[7] Mokienko V.M., Nikitina T.G..(2007). Bolshoi Slovar Russkih Pogovorok. OLMA Media Group, Moscow.

[8] Müller V.K. (2005). Noviy anglo-russkiy slovar. 12-edition, Russian language, Media, Moscow.

[9] Nurieva N., Borisova T., Kulikova M.. Application of Blended Learning in English Fiction Literature Course. ICDTE 2018 Proceedings of the 2nd International Conference on Digital Technology in Education. Bangkok, Thailand - October 10 - 12, 2018, pp. 23-28. ACM New York, NY, USA @2018. DOI:10.1145/3284497.3284504

[10] Osgood, C.E. (1967).The measurement of meaning. Urbana: University of Illinois Press. 12(3), p. 225-239.[Online]. Available: http://dx.doi.org/10.1037/h0070931

[11] Sapir, E. (1929). A study in phonetic symbolism. In Journal of experimental psychology

[12] Shafikova I., Gurova G., Novikov A. Developing English language competence for specialists in rocket and space composite structures. MATEC Web of Conferences 2018, vol. 194 .- Art.no 01051. DOI: 10.1051/matecconf/201819401051.

[13] Torubarova T.V. The problem of absolute knowledge. Metaphysics as intellectual intuition in classic modern European philosophy. (2016) International Journal of 


\section{$2^{\text {nd }}$ International Conference on}

\section{SOCIAL SCIENCE, HUMANITIES \& EDUGATION}

Environmental and Science Education, 2016, vol. 11, no. 11, pp. 4910 - 4920. [Online]. Available: http://www.ijese.net/arsiv/137

[14] Tyurikov A. G., Kosarenko N. N., Gvozdeva T. B., Voronina M. V., Grishnova E. Y., Solovyeva N. A. New social reality in the context of information and communication technologies. XLinguae 2018, vol. 11 , no. 3, pp. 67 - 75. [Online]. Available: http://www.xlinguae.eu/2018_11_03_06.html. DOI: 10.18355/XL.2018.11.03.06

[15] Wagner, R. The psychological reality of iconism and its impact on the English language. [Online]. Available: https://www.academia.edu/7038443/The 